\title{
Teaching particular languages
}

\section{ENGLISH}

86-495 Crookall, David (U. of Toulon, France) and Watson, Rod (U. of Manchester). Some applied and theoretical perspectives on a jigsaw reading exercise. ITL (Louvain), 69 (1985), 43-79.

An original jigsaw reading activity for foreign-language learners is described. The exercise is made up from young people's L1 books, which are separated into texts, titles (which go with texts), pictures and captions (which go with pictures). These elements are mixed up and students receive a file consisting of three series of elements. Their task is to reconstruct the original combination. Practical considerations of the use of this activity in the classroom and the more theoretical implications of the jigsaw reading technique for foreign language learning are discussed. The issues include: the rationale and nature of jigsaw reading; ethnomethodological and applied linguistics perspectives on reading and on jigsaw reading; the pedagogic use of text; the type of language used in the exercise described and its congruence with theories of language acquisition and of reading activity in a foreign language.

86-496 Glaap, Albert-Reiner. Idiomatisches Englisch = besseres Englisch? [Does idiomatic English equal better English?] Sprache und Literatur [formerly Linguistik und Didaktik], (Munich, FRG), 56 (1985), 95-104.

The teaching of idioms may be appropriate in the upper classes of the German grammar school, helping to promote awareness of language. Pupils can be introduced to different types of idiom, some syntactically anomalous, some surprisingly parallel to German ('to see red'), others requiring understanding of history or institutions ('to take silk'). Idioms may be explored in test-based work [example using an Ayckbourn play]. Reference books [three briefly reviewed] can help teachers and learners. Idioms should be taught primarily for receptive purposes, and pupils should learn to use them only sparingly in production, as over-use can be a 'verbal disaster'. Guided production exercises can, however, lead to an awareness of pragmatic appropriacy as well as semantic content, and thus to productive competence.

86-497 Maher, John (U. of Edinburgh). The development of English as an International Language of Medicine. Applied Linguistics (Oxford), 7, 2 (1986), 206-18.

As a medium of international communication in several spheres, including science and technology, English has largely replaced - on a global scale - many other regional lingua francas. The purpose of this paper is to evaluate the extent to which English is used in one particular sphere: as an international and intranational language of medical communication. The data presented here are designed to show the develop- 
ment of English as a medium of biomedical literature in several countries from a longitudinal perspective. A database (MEDLINE Index Medicus) was used in this analysis. The results indicate that the use of English is increasing and that English appears to have growing intranational as well as international currency in medical communication.

A brief sociolinguistic profile of the role of English among the medical profession of one of the countries surveyed - Japan - is also presented. This uses the results of a recent linguistic investigation carried out by the author in clinics and medical schools in Japan. In Japan, where knowledge and 'information' are regarded as key natural resources or raw material, English possesses a unique role as vehicle or mediator of such resources.

In describing earlier lingua francas and their continuing influence, the author points also to the implications of the internationalisation of English in the sociology of knowledge and to the further implications for the teacher of English for medical purposes. As is the case with technical jargon, the use of English may potentially inhibit communication between doctor and patients in a non-English-speaking environment. This may serve to reinforce the inherent power relation, enhance professional or group identity, and promote the mystification of specialised knowledge.

86-498 Meara, Paul (Birkbeck Coll., U. of London) and others. Hidden reading problems in ESL learners. TESL Canada Journal (Montreal, Canada), 3, 1 (1985), 29-36.

This article reports a case of a native speaker of Spanish who has severe reading and spelling difficulties in English. These difficulties resemble those found in surface dyslexia. It is argued that he also has the same difficulties in Spanish, but the regular spelling system of Spanish prevented his difficulties from becoming apparent. It is possible that the writing system of a speaker's L1 can strongly influence the way he/she habitually handles words both in the L1 and in an L2, and the implications of this view for teaching English as a second language are discussed.

86-499 Nolasco, Rob and Arthur, Lois (Centre for British Teachers Ltd., London). You try doing it with a class of fortyl ELT Journal (London), 40, 2 (1986), 100-6.

The difficulties experienced by some British teachers in introducing communicative techniques in the secondary classroom in Morocco led to an examination of the problem of innovation in English-language teaching at school level. The teachers' perceived difficulties are discussed, and it is argued that teachers need to take account of learners' expectations and introduce change gradually. The introduction of change should also include an element of learner training; a 10-week plan for introducing students to and training them in the use of pair and group work is outlined. 


\section{Teaching particular languages}

86-500 Swales, J. M. (U. of Aston in Birmingham). English language papers and authors' first language: preliminary investigations. Scientometrics (Amsterdam), 8, 1/2 (1985), 91-101.

The paper argues for greater linguistic sensitivity in scientometric research. It discusses recent research by Baldauf and Jernudd, and raises issues of North/South, English/non-English imbalance in research communication. It then proposes a procedure for identifying on textual evidence native/non-native speaker status of authors in English periodical literature. Preliminary application to 623 articles is reported and evaluated. The Health Science NNS (non-native speaker) percentage was 23 per cent; in Economics, half that figure. In both there were few papers of third-world provenance: this supports the findings of Baldauf and Jernudd. Scientometric research could contribute to the teaching of Research English and thus help to redress the suspected imbalance.

\section{FRENCH}

86-501 Calbris. Geneviève (ENS de Saint-Cloud, CREDIF). Geste et parole. [Gesture and speech.] Langue Française (Paris), 68 (1985), 66-84.

Numerous examples are given of (French) gestures and their meanings, both from the language system (dictionary definitions) and from observed use (mainly film and television). The latter are divided into gestures which replace an utterance, which complete it and which accompany it, either complementary or (roughly) synonymous. Reasons for using gesture include necessity, economy, and mitigation or its opposite, but the author draws special attention to the ability of gesture to make the abstract more concrete and vice versa. As gesture is culture-specific - in one experiment, French social gestures were correctly interpreted by $85 \%$ of French subjects, $29 \%$ of Japanese - it requires attention in language teaching.

86-502 Coste, Daniel (ENS de Saint-Cloud, CREDIF and CNRS). Sur quelques aspects des relations récentes entre grammaire et didactique de français langue étrangère. [Some aspects of the recent relationship between grammar and French foreign language teaching pedagogy]. Langue Française (Paris), 68 (1985), 5-17.

The core areas of linguistics, especially grammar, have in the last 30 years lost much of their influence on French language teaching pedagogy. Reasons include the perceived failure of methods (audiolingual) based on old theories, the limited penetration of new theories (transformational grammar), and the attraction of peripheral areas such as discourse, pragmatics and register studies. But language teaching cannot get away from grammar, and it is now re-emerging in various forms, from coursebook presentations, and supplementary materials which are undisguised grammar exercises, to articles in journals for teachers and research projects. Treatment of grammar is fragmentary and it is still unclear how to fit the pieces back together. 
86-503 Duda, Richard (U. of Nancy II) and Parpette. Chantal (ENTPE. Lyon). La perception culturelle chez les stagiaires étrangers en France. [The cultural perception of foreign trainees in France.] Dialogues et Cultures (Paris), 27 (1985), 20-30.

The foreigner learning French in France needs to become familiar with a different urban environment. Two groups of students, at Lyon and at Nancy, the majority from Latin America and Indonesia, and taking courses in French prior to proceeding to engineering training, took part in tests and activities designed to assess their perception of their environment and their reactions to it.

They were shown extracts from video films without sound tracks and their interpretations compared with those of native French speakers. They were asked to fill in a questionnaire on their attitudes towards France and the French; study one of the suburbs of the town where they were staying; locate and find their way to certain buildings or institutions in these cities; draw a mental map of the town; and take photographs of the things they found most unusual in France.

Some of these activities could be adapted for use with students outside France. In either case, the acquisition of cultural competence by the students is dependent on the parallel acquisition on inter-cultural competence on the part of teachers and trainers.

86-504 Milot, Jean-Guy and Ayot, Hélène (CECM, Montreal). Un instrument pour comparer les pratiques d'enseignement. [A method for comparing practices in teaching.] Dialogues et Cultures (Paris), 27 (1985), 45-53.

At the 1984 Congress of the FIPF it was suggested that a comparative table of practice in the teaching of French world-wide (both as foreign language and mother tongue) should be drawn up. The following parameters are suggested for the construction of such a table: aims and objectives of teaching; types of activity; media used; relation to the learner; physical and institutional framework. [Examples of tables.]

86-505 Ngalasso. Mwatha Musanji (U. of Bordeaux III). Vivre le français en Afrique. Mais quel français? [Long live French in Africa. But what kind of French?] Dialogues et Cultures (Paris), 27 (1985), 11-19.

In francophone Africa, French is an élitist, minority language, associated with intellectual, political and economic power and closely linked to upward social mobility. For the overwhelming majority of the population it remains a foreign language, while African languages and the traditional oral culture of which they are the expression are excluded from prestige and authority.

French needs to be better taught: modern living French, not dead classical French, using methods appropriate to African conditions and paying due regard to the special characteristics of African French. African languages must be accorded their rightful place in local government administration and in education. French is learnt better when the child's mother tongue is used as the medium of instruction in primary school and French is introduced later on. African languages must be developed as the vehicle 


\section{Teaching particular languages}

of African identity. The importance of French, its foreignness frankly recognised, will be in no way diminished, given its role as the language of international communication, higher education and advanced technology.

86-506 Pellerin, Micheline and Hammerly. Hector. L'expression orale après treize ans d'immersion française. [Oral performance after 13 years of French immersion.] Canadian Modern Language Review (Toronto), 42, 3 (1986), 592-606.

Conversations with six Grade Twelve students who had been in French immersion programme beginning in kindergarten were recorded and analysed for the purpose of evaluating their oral performance and comparing it with the results of other studies. It was found that the number of incorrect sentences produced by these students ranged from 40.3 to $72.4 \%$, with a mean of $55.3 \%$, that is, not counting false starts, etc. The fact that this reveals little progress from Grade Six (as studied by Spilka, 1976) would seem to indicate that this very faulty interlanguage is fossilised before Grade Six. Certain advantages and drawbacks of French immersion are discussed. The article ends with suggestions for a revised French immersion programme.

86-507 Trévise, Anne and Porquier, Rémy ( $U$. of Paris $X$ and GRAL). Acquisition d'une deuxième langage en milieu naturel: quelles méthodologies de description? [Acquiring a second language naturally: what descriptive methods?] Langue Française (Paris), 68 (1985), 18-31.

Studies of the acquisition of French by Spanish-speaking Latin American refugees recently arrived in France and without any previous knowledge of the language are being carried out as part of the European project 'Second language acquisition by adult immigrants'. The interlanguage developed by one such refugee is analysed here with particular reference to person, predicate and spatial concepts. Areas of difficulty occur where Spanish cognitive categories differ from those of French.

It was not possible to measure the subjects' understanding of spoken French. Yet it is through their comprehension of the French input they receive that learners construct their interlanguage. The marginal social position occupied by immigrants must also affect their language learning. In the long term, further study of interlanguage will make it possible to identify the psychological and linguistic constants present in all language acquisition situations.

86-508 van Straalen-Sanderse, Wilma (U. of Leyden) and others. Erreurs grammaticales: comment s'entrainer à les dispister. [How to train students to spot grammatical errors.] Français dans le Monde (Paris), 198 (1986), 57-62.

The ability to produce correct grammatical sentences does not necessarily imply the capacity to detect and correct grammatical errors. Training in this specific skill is indicated and a three-stage programme is therefore proposed. Stage one: the student is presented with a series of pairs of sentences (one grammatical, one ungrammatical) and is asked to select the correct sentence, justifying his or her choice. Stage two: the 
sentences presented are no longer minimal grammatical pairs - however, the student may be given some assistance at first by being told the number of errors to be detected. Stage three: real life texts may be used; later students progress to correcting their own work and that of other students; they are required to detect the errors, put them right and give their reasons [examples]. [A test of students' ability to detect errors and produce correct sentences is included.]

68-509 Vives, Robert (U. of Paris VIII). Lexique-grammaire et didactique du français langue étrangère. [Lexis-grammar and French foreign language teaching methodology]. Langue Française (Paris), 68 (1985), 48-65.

The term 'lexis-grammar' is used for a description of the syntactical, distributional and transformational properties of verbs, nouns and adjectives in simple clauses, as undertaken by Gross and others. Some verbs, such as drink, impose selectional restrictions on their subject and complement; other, semantically empty verbs such as have do not, but may form part of a verbal phrase which does, e.g. have an evil influence. [Research on constructions with être, avoir, faire, donner, reçevoir is reported]. FL dictionaries should give information on networks of related forms (e.g. controls, has control of, loses control of, is controlled by, is under the control of) and that such networks should be explored during the teaching/learning process.

\section{6-510 Walz, Joel. Is oral proficiency possible with today's French textbooks? Modern Language Journal (Madison, Wis), 70, 1 (1986), 13-20.}

An examination was undertaken of 22 textbooks (published in the USA) for the teaching of college French at the elementary level, all published or re-edited within the last five years. The areas studied were: aims, phonology (pronunciation), morphology (How are the differences between oral and written forms resolved?), syntax of spoken French. Despite a generation of emphasis on the speaking skill, pedagogical grammars are still based on the traditional form, the written language. It is of course easier to represent the written language in a written medium and students are used to learning it. In French, written forms are often superficially simpler, e.g. numbers and prenominal adjectives. Only three out of the 22 books explain the oral forms of the language consistently and use them to structure their presentations. Ten other books mention oral forms inconsistently, and the other nine use only the written language in their explanations. Many books include language forms (written forms) simply because they exist - these should be eliminated in the interests of simplification. Many books fail to take account of oral complexity, teaching too much too soon. They do not take current usage into account, hence advanced students have difficulty understanding spoken colloquial French, and they themselves sound 'textbookish'. A step in the right direction is that several books include open-ended activities where students can supply original sentences and communicate with each other. In other respects, however, textbook writers will have to pay considerable attention to the description and ordering of the language to be learned, if the goal of oral proficiency is to be met. 


\section{Teaching particular languages}

\section{GERMAN}

86-511 Bykova, Olga. Methodologische Grundlagen der linguo-stilistischen Interpretation eines belletristischen Textes. [Methodological fundamentals in the linguo-stylistic interpretation of a literary text.] Deutsch als Fremdsprache (Leipzig, GDR), 22, 6 (1985), 349-53.

The author stresses the importance of the linguo-stylistic analysis of an artistic text in the teaching of advanced students of foreign languages training to be teachers. The problems of literary interpretation in general are discussed and the contributions to be expected from different disciplines, such as psycholinguistics, linguistics and literary theory, are evaluated. The author highlights the need to supplement the biographical approach to a text by a literary theory and method which brings out the way the text reflects reality and which demonstrates the dynamic nature of the literary text. The article concludes with a set of 'instructions' which students can follow when dealing with a descriptive text.

86-512 Harroff, Stephen (Indiana U. - Purdue U.) A microworld for secondlanguage acquisition. CALICO Journal (Provo, Utah), 3, 3 (1986), 31-3.

This article describes a German-language microworld for fostering language acquisition - for learning a computer language through a natural language. INFORMATIK $I$ is a course on the nature of language, on CAI, and on the programming language, SuperPILOT, a course in which German is the medium for communicating and learning. Following the course description is that of a disk-based tutorial on the instruction set of SuperPILOT. This tutorial reflects the premise of the course, that experimentation fosters comprehension, and includes a series of laboratory experiments for students to complete - all in German.

\section{SPANISH}

86-513 Long, Sheri Spaine (U. of California, LA). A strategy for long term role-play in the second language classroom. Foreign Language Annals (New York), 19, 2 (1986), 145-8.

This paper describes a long-term (eight-week) model role-play project applicable to adult-, college-, and secondary-level second-language classes, in which students create and adopt an assumed identity. The result of this strategy is greater variety in the students' acquired vocabulary, improved written work, enriched cultural knowledge, and a far from routine classroom atmosphere.

86-514 Macian, Janice L. (Ohio State U.). An analysis of state adopted foreign language textbooks used in first- and third-year high school Spanish classes. Foreign Language Anna/s (New York), 19, 2 (1986), 103-18.

Using the Annehurst Curriculum Classification System as a tool for classifying, describing, and analysing first- and third-year high-school Spanish textbooks, this study provides information about the curriculum characteristics of these textbooks 


\section{Spanish 371}

and determines what differences exist among the texts evaluated. The characteristics are: experience, intelligence, motivation, emotion/personality, creativity, sociability, verbal expression, and auditory, visual, and motor perception.

Results of this study indicate that these textbooks are consistently 'deficient' on nearly all of the dimensions examined. Similarity of characteristics among first- and third-year Spanish textbooks suggests that the broad spectrum of cognitive and affective needs inherent in learners is not being met. 